九州大学学術情報リポジトリ

Kyushu University Institutional Repository

Implementation Degree of Agricultural Decisions at the Egyptian Farm Level and the Expected Role to the Agricultural Extension: a Comparison with Japan

Elhamoly, Adel I. M. A. Branch of Agricultural Extension, Department of Agricultural Economics, Faculty of Agriculture, Kafrelsheikh University

Nanseki, Teruaki

Laboratory of Agricultural and Farm Management, Dept of Agricultural and Resource Economics, Faculty of Agriculture, Kyushu University

Shinkai, Shoji

Department of Food and Health Sciences, Fukuoka Women's University

https://doi.org/10.5109/20340

出版情報: 九州大学大学院農学研究院紀要. 56 (2)，pp.417-424，2011-09. 九州大学大学院農学研究院 バージョン：

権利関係 : 


\title{
Implementation Degree of Agricultural Decisions at the Egyptian Farm Level and the Expected Role to the Agricultural Extension: a Comparison with Japan
}

\author{
Adel I. M. A. ELHAMOLY ${ }^{1}$, Teruaki NANSEKI ${ }^{2 *}$ and Shoji SHINKAI ${ }^{3}$

\begin{abstract}
Laboratory of Agricultural and Farm Management, Diversion of International Agricultural Resource Economics and Business Administration, Department of Agricultural and Resource Economics, Faculty of Agriculture, Kyushu University, Fukuoka 812-8581, Japan and Branch of Agricultural Extension,
\end{abstract} \\ Department of Agricultural Economics, Faculty of Agriculture, Kafrelsheikh University, 33516, Kafr El-Sheikh, Egypt \\ (Received April 27, 2011 and accepted May 9, 2011)
}

\begin{abstract}
This research has an attempt to determine the implementation degree of farm managers to the extent in which agricultural decisions are made at the farm level (ADI) in Egyptian farms with a comparison with Japan. Also, this research investigates the existing agricultural service centers that benefits farmers in Egypt. Besides it determines the environmental barriers which are facing Egyptian sample while implementing to their decisions.

Data collection was carried out with 195 Egyptian farm managers in the form of interview with questionnaire. Then, the same set of questionnaire was translated in Japanese version, and 550 copies were sent out to Japanese farmers by mail. However, only 36 copies were returned. The results from the surveys show that the agricultural cooperatives and agricultural shopping \& companies are important services centers for Egyptian and Japanese farmers, and most of interviewees had benefited from contact with these centers. Also, about 83\% of Egyptian sample (E.S) and 39\% of Japanese sample (J.S) had degree ranging between low and moderate of agricultural decisions implementation (ADI). Finally, the significant barriers to E.S were absence of agricultural extension role in the new areas, lack of the industry system in the farm, lack awareness of farmers of the organic- agriculture, agricultural intensification, agricultural industrialization, agricultural pre-marketing processes and the proximity of training centers that is too far from the farmer's villages.
\end{abstract}

Keywords: Farm Manager, Agricultural Decision Implementation (ADI), Agricultural Extension, Service Centers, Pre-marketing, Modernization, Industrialization, Barriers.

\section{INTRODUCTION}

Agricultural sector plays an important role among the various productive sectors, in any country, especially in Egypt. The Egyptian agricultural sector contributes about $13.4 \%$ of the gross national product, occupies about $27 \%$ of the total labor force, and the value of agricultural exports about 900 billion dollars. Moreover, it is successfully succeeded in minimizing the food security risk, which achieved self sufficiency by the rates of $75 \%$ of meat, $70 \%$ of sugar, and $85 \%$ of wheat (Egyptian ministry of agriculture land reclamation, 2008). In addition, it has a crucial role in providing necessary materials for a number of important industries.

Development of agricultural sector is one of the main political goals in many countries - especially in Egypt to improve the living standards of their people through the optimal use of the natural and human resources, because the rural population is important part for any society (CAPMAS, 1997, p. 19). Therefore devel-

1 Branch of Agricultural Extension, Department of Agricultural Economics, Faculty of Agriculture, Kafrelsheikh University, Egypt

2 Laboratory of Agricultural and Farm Management, Dept of Agricultural and Resource Economics, Faculty of Agriculture, Kyushu University, Japan

3 Department of Food and Health Sciences, Fukuoka Women's University, Japan

* Corresponding author (E-mail: nanseki@agr.kyushu-u.ac.jp) opment of this sector in Egypt is one of the most important current issues to be carried out increase its contribution to the national production and improve the living economical and social conditions of the rural population, through human resources development in this sector (capabilities of the change agents, audiences), and unbehavioral aspects development (technique, economic, technology aspects, ....) because the human is main support to the development process (Sanders, 1966, p. 299).

The success in achieving agricultural development in terms of range and pace to a great extent is meant to reduce the gap between the findings of the research centers and farmers responses to the application in their farms, which in turn, depends on the effectiveness and efficiency of agricultural extension system, which have transferring of these technologies to the farmers and help them implement their decisions in the farm because the agricultural extension is one of the agricultural development systems (Swanson, 1984, p. 20) and it hurry to this process (Mosher, 1966, pp. 10-12).

So, this process depends on the farmers who are agricultural decision makers and implementer at the same time. The event of agricultural decision making process depends on what the farmers have in hand such as knowledge, skills and attitudes related to the agricultural recommendations, which play a main role in shaping their decisions and the degree of implementation of these decisions correctly because Rogers' model had five stages to the innovation-decision process were knowl- 
edge, persuasion, decision, implementation, and confirmation (Rogers, 2003, p. 162).

This study will concern of only the implementation stage. Thus, the implementation degree of the farmers, for their agricultural decisions taken in their farms, reflects quantity and quality of their knowledge, skills, and attitudes, related to these decisions. Moreover, it is also depending on information and the effectiveness of agricultural extension programs and activities available for them.

Accordingly, this research is striving to provide an actual picture of the implementation of the agricultural decisions by some farm managers by comparing the cases between Egypt and Japan. Its results will help Egyptian policy makers in making decision for agricultural policies and preprograms for encouraging new farm managers to implement their agricultural decisions in their farms. In addition, it also aims at providing recommended solutions for the environmental barriers which are facing the farmers when they are implementing their decisions. Finally it may help the agricultural extension workers in planning of extension programs to help farmers for make suitable agricultural decisions.

Therefore, the identification of the research problems is in the following questions: what is the implementation degree of some agricultural decisions (marketing, modernization, and industrialization)?, what are agricultural service centers to the farmers in Egypt and Japan?, what is degree of their benefit from it to help them?, and what are the environmental barriers faced by Egyptian farmers during the implementation these decisions in their farms?

\section{RESEARCH OBJECTIVES}

\section{This research aims to:}

1- Investigate the available agricultural service centers to the two surveys and their contacts with it.

2- Determine their benefit degree from the agricultural service centers.

3- Determine degree of implementation of some agricultural decisions at the farm level in three agricultural fields (agricultural marketing, agricultural modernization and agricultural industrialization fields) for the two surveys.

4- Identify the environmental barriers faced by Egyptian farm managers while implementing some agricultural decisions.

5- Determine the expected role of the Egyptian agricultural extension to help in the farm decisions implementation in the study area.

\section{METHODOLOGY}

\section{Research area:}

Survey samples were selected from Kafr El-Sheikh Governorate in Egypt, because it is mainly an agricultural governorate, consisting of many new societies for the young farmers, and also important governorate for the Egyptian national economy. So, we selected the new communities for farmer's youth in El-Hamoul district. In Japan, we selected Fukuoka Prefecture as our research area because Japan is one of the progress countries especially in the agricultural sector, have effective agricultural extension system, and agricultural information sources.

\section{Research populations and surveys:}

The research populations are those farm managers in the Elzawia and Elmansour areas in Egypt. Surveys were drawn from total population, about $10 \%$ out of total. The total questionnaires collected from Egyptian Surveys (E. S) were 195 cases. For a comparison with Japan, Yame areas in Fukuoka prefecture has been selected as survey field. However, only 36 out of 550 questionnaires which sent to farmers by mail were returned.

\section{Data collection and analysis:}

The questionnaire carefully designed to collect data by the personal interviews with $\mathrm{E}$. S the same set of questionnaire was translated into Japanese language and sent to the J. S. by mail. Main statistical methods used for the data analysis included: percentage, mean, standard division, and frequencies. SPSS program and Microsoft Excel were used to analyze the quantitative data.

\section{Operational Definitions:}

- The Manager offarm: means a person who manages the farm.

- Implementation degree of agricultural decisions: can be identified as implementation degree of interviewees to some agricultural decisions in three fields (agricultural marketing field, agricultural modernization field, and agricultural industrialization field).

This variable is composed of three elements or axes namely agricultural marketing, agricultural modernization, and agricultural industrialization. In the agricultural marketing axis: it has been measured by four decisions which were preparation agricultural products for marketing, choosing marketing agents to sell agricultural products, selling agricultural products, and storing agricultural products. In the agricultural modernization axis: it has been measured by four decisions consisting of using agricultural intensification system "two crops in the same time," using organic agriculture techniques on the farm, attending agricultural training activities and programs, and recycle agricultural wastes on the farm. In the agricultural industrialization axis: it has been measured by four decisions including preparing farm products for industrialization on the farm, executing industrialization treating on the farm, using mechanical industrialization methods on the farm, and providing standard specification of processed products on the farm.

To measure this variable we asked the previous decisions for the managers (farmers), did the manager implement these decisions on the farm, or did manager implement and stop?, or did not manager implement 
these decisions? Then the manager is requested to give " 2 " degrees if manager implemented a decision from these decisions and continued the implementation, or give " 1 " if manager did implement and stop, or give " 0 " if manager did not implemented a decision from his or her decisions. So, the maximum ideal degree in every axis from this axes that can be obtained in all decisions was "8", and the minimum ideal degree was "0". Also, the maximum of the total ideal degree for all decisions in three axes (12 decisions) was " 24 ", and the minimum ideal degree was " 0 ". While the actual degree based on the answer to the questions from interviewees.

\section{THE RESULTS}

\section{1- The contact with available agricultural service centers:}

The results in Fig. 1 showed that the most important agricultural service center was agricultural co-operative societies for E. S and J. S by $100 \%$ and $83.3 \%$, respectively, and the second most important was the agricultural shops and companies by $97.4 \%$ and $77.8 \%$ respectively. On the other hand, in the third place to the E. S is the prefecture agricultural committee office by $83.3 \%$, then rice research center by $54.4 \%$, cereal crops research center by $51.8 \%$, faculty of agricultural by $29.2 \%$, agricultural extension center by $13 \%$, irrigation development center by $5.6 \%$. Whereas for the J. S, the third most important is the agricultural extension center by $56 \%$, then the prefecture agricultural committee office by $36.1 \%$, irrigation development center by $30.6 \%$, then faculty of agriculture by $27.8 \%$, food proceeding research center by $25 \%$, rice research center by $19.4 \%$, and cereal crops research center by $5.6 \%$.

When comparing between the two surveys indicated in the Fig. 1, it could be observed that the agricultural cooperative societies were playing an important role in providing farmers the agricultural knowledge and information. Also, the agricultural shops and companies started playing an effective role in that by selling and buying of the agricultural requirements to the farmers. The E. S does not contact with the food processing research center but quarter of the J. S contacts with it.
The agricultural extension center and faculty of agriculture were very later in providing the agricultural knowledge to the Egyptian farmers.

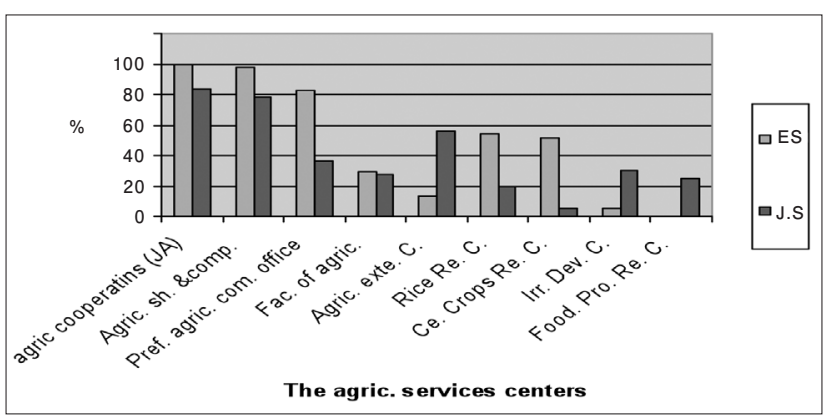

Fig. 1. The contact of the two surveys with available agricultural service centers.

\section{2- The degree of utilization from agricultural serv- ice centers:}

The results in Table 1 showed that the agricultural cooperation's and agricultural shopping and companies were ranked in the first and second places to be utilized by the interviewees of the two surveys, followed by prefecture agricultural committee office by $61.5 \%$ in the third rank for the E. S. On the other hand another service centers were low or very low in terms of utilization degree by farm managers in the two surveys.

\section{3- Implementation degree of agricultural decisions at the farm level:}

The results in Table 2 demonstrated that $23.1 \%$ of E. S was low implementation degree for their agricultural decisions, $60 \%$ of them were moderate degree, and $16.9 \%$ of them were high implementation degree. But, as for the J. S about $11.1 \%$ of them were low implementation degree for their agricultural decisions, $27.8 \%$ of them were moderate degree, and $61.1 \%$ of them were high implementation degree.

When we compare the two surveys, it can be noted that about two-thirds of the J. S had high degree of implementation for their agricultural decisions, while this percentage for E. S was only $16.9 \%$. Also, $60 \%$ of

Table 1. Descriptive of the two surveys according to utilization from agricultural service centers

\begin{tabular}{|c|c|c|c|c|c|c|c|c|c|c|c|c|}
\hline \multirow{3}{*}{ The agricultural services centers } & \multicolumn{6}{|c|}{ E. S } & \multicolumn{6}{|c|}{ J. S } \\
\hline & \multicolumn{3}{|c|}{ Utilize } & \multicolumn{2}{|c|}{ Not } & \multirow{2}{*}{ total } & \multicolumn{3}{|c|}{ Utilize } & \multicolumn{2}{|c|}{ Not } & \multirow{2}{*}{ total } \\
\hline & $\mathrm{n}$ & $\%$ & $\mathrm{R}$ & $\mathrm{n}$ & $\%$ & & $\mathrm{n}$ & $\%$ & $\mathrm{R}$ & $\mathrm{n}$ & $\%$ & \\
\hline Agricultural cooperation's (JA) & 151 & 77.4 & 1 & 44 & 22.3 & 195 & 28 & 77.8 & 1 & 2 & 5.6 & 30 \\
\hline Agricultural shopping \& companies. & 142 & 72.8 & 2 & 48 & 24.6 & 190 & 25 & 69.4 & 2 & 3 & 8.3 & 28 \\
\hline Prefecture Agricultural committee office & 120 & 61.5 & 3 & 42 & 21.5 & 162 & 3 & 8.3 & 7 & 10 & 27.8 & 13 \\
\hline Rice Research Center. & 93 & 47.7 & 4 & 13 & 6.7 & 106 & 4 & 11.1 & 6 & 3 & 8.3 & 7 \\
\hline Cereal Crops Research Center. & 89 & 45.6 & 5 & 12 & 6.2 & 101 & 1 & 2.8 & 9 & 1 & 2.8 & 2 \\
\hline Faculty of agriculture. & 47 & 24.1 & 6 & 10 & 5.1 & 57 & 2 & 5.6 & 8 & 8 & 25.0 & 10 \\
\hline Agricultural extension Center. & 8 & 4.1 & 7 & 18 & 9.2 & 26 & 9 & 25.0 & 3 & 11 & 30.6 & 20 \\
\hline Irrigation Development Center. & 7 & 3.6 & 8 & 4 & 2.1 & 11 & 5 & 13.9 & 5 & 6 & 16.7 & 11 \\
\hline Food Processing Research Center. & 0 & 0 & 9 & 0 & 0 & 0 & 6 & 16.7 & 4 & 3 & 8.3 & 9 \\
\hline
\end{tabular}


Table 2. Descriptive of the two surveys according to degree of the agricultural decisions implementation

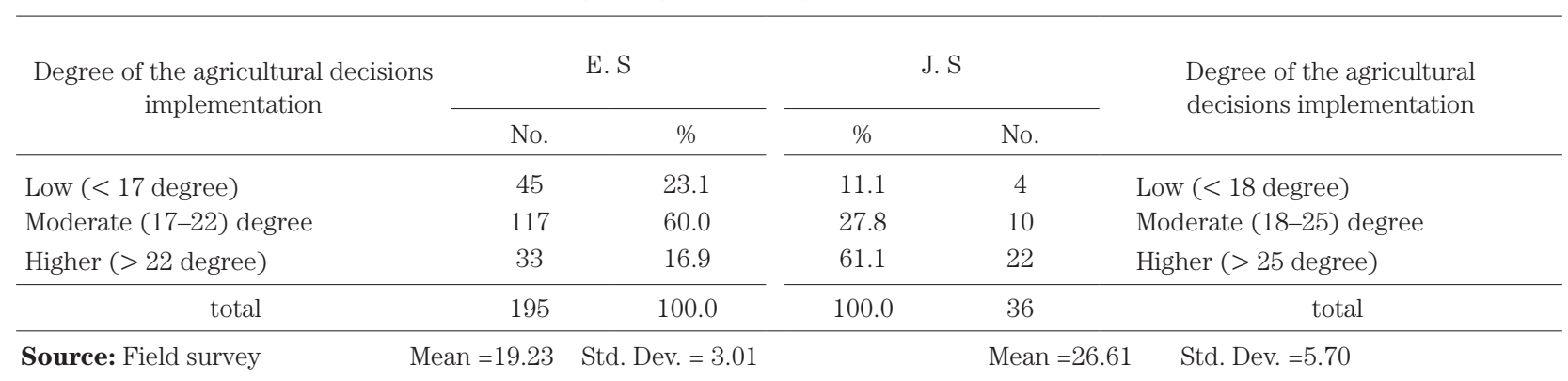

the E. S had moderate implementation degree for their decisions against about a third of J. $\mathrm{S}$ in the same category. Lastly, about $23.1 \%$ of the E. S had low degree whereas it was only $11.1 \%$ for J. S in the same category. Lastly, about $23.1 \%$ of the E. S had low degree whereas it was only $11.1 \%$ for J. S.

This results show large percentage of E. S is not implement their decisions. This may be due to low awareness of $\mathrm{E}$. S about realization high income from their farms, lack of suitable agricultural information to E. S because due to lack number of available agricultural information sources and it doesn't effective, low of technologies and facilities to the implementation and absences of a clear agricultural policy to support the small farms. In addition absences of the agricultural extension activities due to unavailable political support to the extension works (Elhamoly and Nanseki, 2009, P. 532).

\section{For more explanation that:}

A- Agricultural marketing field: The results in Table 3 showed that $97.9 \%$ of E. S prepares their agricultural products to marketing but $2.1 \%$ of them don't implement. Moreover, $97.4 \%$ of them choose marketing agents to sell their agricultural products by themselves whereas $2.6 \%$ of them don't implement. Nevertheless, $91.3 \%$ of them sell some of their agricultural products. Last but not least, $75.9 \%$ of them store some of their agricultural products, and $24.1 \%$ of them don't store.

As for the J. S, the results showed that about 83.3\% of them prepare their agricultural products and choose marketing agents for selling their products. On the other hand, $16.7 \%$ of them do not implement these decisions. Also, $69.4 \%$ of them sell some of their agricultural products, and $80.5 \%$ of them store some of these products. While $30.4 \%$ and $19.5 \%$ of them respectively, did not implement these decisions on their farms.

When comparing between the two surveys can be observed that majority of E. S implement their decisions in agricultural marketing field. Also, the same goes for the J. S but about a quarter of them make their decisions in agricultural marketing field.

B-Agricultural modernization field: The results for E. S indicated in Table 4 show that $33.8 \%$ of inter-

Table 3. Descriptive of the two surveys according to implementation of their agricultural decisions in the agricultural marketing

\begin{tabular}{|c|c|c|c|c|}
\hline \multirow[b]{2}{*}{ The agricultural marketing } & \multicolumn{2}{|c|}{$\%$ E. S. } & \multicolumn{2}{|c|}{$\%$ J. S. } \\
\hline & Imp. & $\begin{array}{l}\text { Don't } \\
\text { Imp. }\end{array}$ & Imp. & $\begin{array}{c}\text { Don't } \\
\text { Imp. }\end{array}$ \\
\hline - Preparation agricultural Products to marketing. & 97.4 & 2.6 & 83.3 & 16.7 \\
\hline - Choosing marketing agents to buy agricultural Products. & 97.4 & 2.6 & 83.3 & 16.7 \\
\hline - Selling some agricultural products. & 91.3 & 8.7 & 69.4 & 30.6 \\
\hline - Storing some agricultural products. & 75.9 & 24.1 & 80.5 & 19.5 \\
\hline
\end{tabular}

Table 4. Descriptive of the two surveys according to implementation of their agricultural decisions in the agricultural modernization

\begin{tabular}{|c|c|c|c|c|}
\hline \multirow[b]{2}{*}{ The agricultural modernization } & \multicolumn{2}{|c|}{ \% E. S. } & \multicolumn{2}{|c|}{$\%$ J. S. } \\
\hline & Imp. & $\begin{array}{l}\text { Don’t } \\
\text { Imp. }\end{array}$ & Imp. & $\begin{array}{l}\text { Don't } \\
\text { Imp. }\end{array}$ \\
\hline - Using agricultural intensification System (two crops in the same time). & 33.8 & 66.2 & 52.8 & 47.2 \\
\hline - Using organic agriculture techniques on the farm. & 17.4 & 82.6 & 52.8 & 47.2 \\
\hline - Attending agricultural Training activities \& programs. & 14.9 & 85.1 & 77.8 & 22.2 \\
\hline - Recycling some agricultural wastes on the farm. & 8.2 & 91.8 & 77.8 & 22.2 \\
\hline
\end{tabular}

Source: Field survey

$\mathrm{N}=195$

$\mathrm{N}=36$ 
viewees apply agricultural intensification system but $66.2 \%$ of them cannot do that. In addition, $17.4 \%$ of them use some organic agriculture techniques whereas $82.6 \%$ of them do not do it at all. $14.9 \%$ have attended agricultural training programs meanwhile $85.1 \%$ of them do not attend any training courses. Finally, only $8.2 \%$ of the interviewees recycle some of agricultural wastes in their farms, but $81.8 \%$ of them do not.

As for the J. S the results reveal that about 52.8\% against $47.2 \%$ of them apply both agricultural intensification system and organic agricultural techniques. Also, $77.8 \%$ of them have attended agricultural training activities and recycle some of agricultural wastes in their farm whereas $22.2 \%$ of them did neither attend nor recycle the agricultural wastes.

When the two surveys are compared can be noted that a third of $\mathrm{E}$. S had carried out their decision on the application of agricultural intensification system, and only minority of them actually implemented decisions in this field, but majority of them didn't implement these decisions.

On the other hand, more than half of the J. S carried out their decisions on the use of agricultural intensification and organic agricultural systems, but about less than a third of them did not apply in their farms. Also, about three-quarters of them have attended agricultural training activities and recycled some agricultural wastes in their farms, but the minority of them did not do these activities.

C- Agricultural industrialization field: the result of E. S shown in Table 5 indicated that only $11.8 \%$ of interviewees prepare farm products for industrialization against $88.2 \%$. Also 100\% of them did not do each of the following decisions: executing any industrialization treating, using mechanical industrialization and providing standard specification of processed agricultural products.

As for the J. S the results declare that about 83.3\% of them implemented their decision in preparing farm products for industrialization, and using mechanical industrialization. Furthermore, $88.9 \%$ of them implemented their decisions in executing some industrialization treating, and $88.3 \%$ in providing standard specification of processed products.

Comparison of the two research surveys could observe that only $11.8 \%$ of E. S prepare their farm products to industrialization, and none of E. S implement decisions related to industrialization treating, mechanical industrialization and providing standard specification of processed products in their farms. On the other hand, majority of J. S had implemented all decisions related to agricultural industrialization field, and small percentage of them did not implement these decisions.

\section{3- The environmental barriers which hamper imple- mentation of agricultural decisions from the $E$. $S$ view:}

The results in Table 6 showed that the Egyptian interviewees are facing some environmental barriers which hinder them from making agricultural decisions in the farms. These barriers include absence of the agricultural extension role in the new areas by $99.5 \%$, lack of agricultural industry system in the farm by $94.9 \%$,

Table 5. Descriptive of the two surveys according to implementation of their agricultural decisions in the agricultural industrialization

\begin{tabular}{|c|c|c|c|c|}
\hline \multirow[b]{2}{*}{ The agricultural industrialization } & \multicolumn{2}{|c|}{$\%$ E.S. } & \multicolumn{2}{|c|}{$\%$ J.S. } \\
\hline & Imp. & $\begin{array}{l}\text { Don’t } \\
\text { Imp. }\end{array}$ & Imp. & $\begin{array}{c}\text { Don't } \\
\text { Imp. }\end{array}$ \\
\hline - Preparing farm products to industrialization on the farm. & 11.8 & 88.2 & 83.3 & 16.7 \\
\hline - Executing some industrialization treating on the farm. & 0.0 & 100.0 & 88.9 & 11.1 \\
\hline - Using mechanical industrialization methods on the farm. & 0.0 & 100.0 & 83.3 & 16.7 \\
\hline - Providing standard specification of processed products on the farm. & 0.0 & 100.0 & 88.9 & 11.1 \\
\hline
\end{tabular}

Source: Field survey

$\mathrm{N}=195$

$\mathrm{N}=36$

Table 6. The environmental barriers to implementation of agricultural decisions from the E. S view:

\begin{tabular}{|c|c|c|c|}
\hline No & The barriers & $\mathrm{n}$ & $\%$ \\
\hline 1 & Absence of the agricultural extension role in the new areas & 194 & 99.5 \\
\hline 2 & Lack of agricultural industry system in the farm & 185 & 94.9 \\
\hline 3 & Lack of farmer's awareness about important of intensification, industrialization and pre-marketing processes. & 180 & 92.0 \\
\hline 4 & Extension training center so far from farmers villages & 176 & 90.2 \\
\hline 5 & Lack of organic agriculture and industrialization technologies & 164 & 84.1 \\
\hline 6 & The weakness relationship between agricultural res. and farmers & 162 & 83.1 \\
\hline 7 & Low benefit of training programs & 161 & 82.6 \\
\hline 8 & Weakness of available facilities & 159 & 81.5 \\
\hline 9 & The extension training centers didn't invitation to all farmers & 157 & 80.1 \\
\hline 10 & Less quantity of the irrigation water. & 156 & 80.0 \\
\hline
\end{tabular}

Source: Field survey 
lack of farmer's awareness about important of intensification, industrialization and pre-marketing processes by $92 \%$, extension training center is far from farmers' villages by $90.2 \%$, and lack of organic agriculture and industrialization technologies by $84.1 \%$.

Moreover, weak relationship between agricultural research and farmers is presented by $83.1 \%$ as barriers; low benefit of training programs by $82.6 \%$, unavailability of facilities by $81.5 \%$, lack of invitation from the extension training centers by $80.1 \%$, and less quantity of the irrigation water by $80 \%$.

\section{DISCUSSION}

The research results show that degree of the agricultural decisions implementation (ADI) to Egyptian farm managers in the three fields (marketing, modernization, industrialization) is weak. This weak degree is caused by:

- The managers have limited information about these technologies, so that they are not aware of the importance of these agricultural technologies.

- Lack of the agricultural services from agricultural service centers, because some of these centers are only interested in buying and selling without providing learning services to farmers; In addition, weak relationship between agricultural service center and farmers results in ineffectiveness and discontinuity of services provided to farmers.

- Absence of the extension role to the agricultural services centers in this area because the extension organization does not exist in this area or unavailable political support to the extension system in this area, (Elhamoly and Nanseki, 2009, p. 532).

- Absence of entrepreneurial thinking of the Egyptian managers due to lack of awareness, increase of the costs, limited of funding sources, economical safety, difficulty and complexity of the procedures, and being small-scale farmers.

- Lack of the available facilities in the farm.

\section{RECOMMENDATIONS}

1- Establishing an Extension Center in the new area, that contains all the scientific and training facilities to train of the managers of Egyptian farms and disseminate new ideas.

2- Planning and implementing extension programs for managers of the Egyptian farms in all agricultural fields, especially agricultural marketing, agricultural modernizing and agricultural industrializing Fields.

3- Providing appropriate agricultural technologies in organic agriculture and agricultural industry fields.

4- Continuous training for farm managers on how to apply modern agricultural techniques in their farms.

5- Continuous training for the managers of the agricultural services centers on how to create extension awareness with their agricultural services to the managers of Egyptian farms.
6- Finally, this study can present us a plan to the expected roles of Egyptian agricultural extension to help in the farm decisions implementation in the study area by these items:

A- Presenting of the suitable extension recommendations to the managers by extension meetings, prints, posters, visits...etc in agricultural production, marketing and industrialization fields.

B- Presenting of extension massages by multi-media (T.V., radio, newspapers) to managers in the suitable times about how can they increase the income from their farms.

C- Organizing of periodic extension campaigns for managers to discuses the farm barriers in these areas and determine the suitable solutions.

D- Providing the easy contacts with the all agricultural information sources to the managers (for example, by telephone, internet, letters, visits, mobiles...).

E- Building effective exchange relationships between the agricultural research system or agricultural services centers and managers.

F- Encouraging the managers for taking correct farm decisions and implementing in their farms by the materials and non-materials incentives.

G- Providing the marketing information to managers in the suitable time.

$\mathrm{H}-$ Providing continuous training to managers about application of the technologies in their farms.

J- Activating agricultural societies to do their extension and marketing roles in these areas.

$\mathrm{K}$ - Collecting of the small farms in larger farm units to adopt a system agricultural industrialization in these units because the Egyptian farms are very small.

\section{ACKNOWLEDGEMENT}

Our sincere thanks should go to Dr. Ahmed Mounir, Mr. Winston E. Marte, Mr. Maeda and Phonesavanh L. for their participations in the translate of questionnaire to Japanese language and valuable comments on the draft of this paper.

\section{THE REFERENCES}

Central Agency for Public Mobilization and Statistics "CAPMAS", the Annual Statistical Book, Cairo, June 1997, pp. 19

Egyptian ministry of agriculture land reclamation, Data do not publication, 2008

Elhamoly, A. I. \& T. Nanseki, 2009 The Needs of Environmental Extension and the Educational Background of Farm Managers in El-Burollos District at Kafr El-Sheikh Governorate, Egypt: From view points of Knowledge, Implementation and Attitude, J. Fac. Agr., Kyushu Univ., 54 (2): 523-533

Rogers, E. M. 2003 Diffusion of innovations, (5th ed.), New York, NY: The Free Press

Mosher, A. T. 1966 Getting agricultural moving: Essential for development and modernization, the Agricultural development council, New York, U.S.A.

Swanson, B. 1984 Agricultural Extension, A Reference Manual, $2^{\text {nd }}$ edition, F. A. O, Rome, Italy 


\section{Appendix A}

No. $(\ldots . . . .$.

NAME:

1- Do you give the agricultural work?

All time (.....) Half time (.....) some time (...) No time (......)

$2-$ How many years of your work at agriculture?

$$
=(\ldots \ldots \ldots \ldots \ldots . . .) \text { years }
$$

3- How many years of your formal education?

$$
=(\ldots \ldots \ldots \ldots \ldots . . . . . .) \text { years }
$$

\begin{tabular}{|c|c|c|c|c|}
\hline \multirow{2}{*}{ Sources } & \multicolumn{3}{|c|}{ Utilize } & \multirow{2}{*}{$\begin{array}{c}\text { No } \\
\text { Utilize }\end{array}$} \\
\hline & always & sometime & rarely & \\
\hline - Agricultural Cooperation's (JA) & $\cdots \cdots \cdots$ & 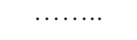 & $\cdots \cdots \cdots$ & $\ldots \ldots \ldots$ \\
\hline Agricultural Shopping \& Companies.- & $\ldots \ldots \ldots$ & $\ldots \ldots \ldots$ & (n...... & -........ \\
\hline - Prefecture Agricultural Committee Office & $\ldots \ldots \ldots$ & $\cdots \cdots \cdots$ & $\cdots \cdots \cdots$ & (n)..... \\
\hline - Rice Research Center. & $\cdots \cdots \cdots$ & $\ldots \ldots \ldots$ & (n).... & (n).... \\
\hline - Cereal Crops Research Center. & $\ldots \ldots \ldots$ & $\ldots \ldots \ldots$ & $\ldots \ldots \ldots$ & $\ldots \ldots \ldots$ \\
\hline - Faculty of Agriculture. & 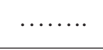 & $\ldots \ldots \ldots$ & $\cdots \cdots \cdots$ & $\ldots \ldots \ldots$ \\
\hline - Agricultural Extension Center. & $\ldots \ldots \ldots$ & $\ldots \ldots \ldots$ & $\ldots \ldots \ldots$ & $\ldots \ldots \ldots$ \\
\hline - Irrigation Development Center. & 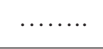 & $\cdots \cdots \cdots$ & (n...... & $\cdots \cdots+$ \\
\hline - Food Processing Research Center. & 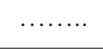 & $\ldots \ldots \ldots$ & 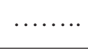 & $\ldots \ldots \ldots$ \\
\hline Another's:..................................... & $\cdots \cdots \cdots$ & $\ldots \ldots \ldots$ & $\cdots \cdots \cdots$ & $\cdots \cdots \cdots$ \\
\hline
\end{tabular}

4- What is the agricultural service centers and degree your utilization from it?

\section{Appendix B}

Please, determine degree of the agricultural decisions implementation and what are the barriers to

\begin{tabular}{|c|c|c|c|c|}
\hline \multirow[b]{2}{*}{ Some Agricultural Decisions } & \multicolumn{3}{|c|}{ Implementation of the Decision } & \multirow{2}{*}{$\begin{array}{c}\text { What are the barriers to } \\
\text { implementation of } \\
\text { agricultural decisions }\end{array}$} \\
\hline & $\begin{array}{l}\text { Implemented and } \\
\text { continued }\end{array}$ & $\begin{array}{l}\text { Implemented } \\
\text { then stop }\end{array}$ & $\begin{array}{l}\text { Didn't } \\
\text { implementation }\end{array}$ & \\
\hline \multicolumn{5}{|c|}{ A- Agricultural marketing field: } \\
\hline - Preparation agricultural Products to marketing. & .......... & .......... & $\ldots+\ldots+\cdots$ & $\ldots \ldots$ \\
\hline \multicolumn{5}{|l|}{$\begin{array}{l}\text { - Choosing marketing agents to buy agricultural } \\
\text { Products. }\end{array}$} \\
\hline - Selling some agricultural products. & $\ldots \ldots \ldots \ldots$ & $\ldots \ldots \ldots \ldots$ & $\ldots \ldots \ldots \ldots$ & \\
\hline - Storing some agricultural products. & $\ldots \ldots \ldots \ldots$ & $\ldots \ldots \ldots \ldots$ & $\ldots \ldots \ldots \ldots$ & \\
\hline \multicolumn{5}{|c|}{ B-Agricultural modernization field: } \\
\hline $\begin{array}{l}\text { - Using agricultural intensification System (two } \\
\text { crops in the same time). }\end{array}$ & & $\cdots \cdots$ & n.w. & \\
\hline $\begin{array}{l}\text { - Using techniques of organic agriculture on the } \\
\text { farm. }\end{array}$ & & & & \\
\hline $\begin{array}{l}\text { - Attending agricultural Training activities \& } \\
\text { programs. }\end{array}$ & n........ & ......... & $\ldots \ldots$ & \\
\hline - Recycling some agricultural wastes on the farm. & $\ldots \ldots \ldots \ldots$ & $\cdots$ & & \\
\hline
\end{tabular}
implementation of these decisions? 


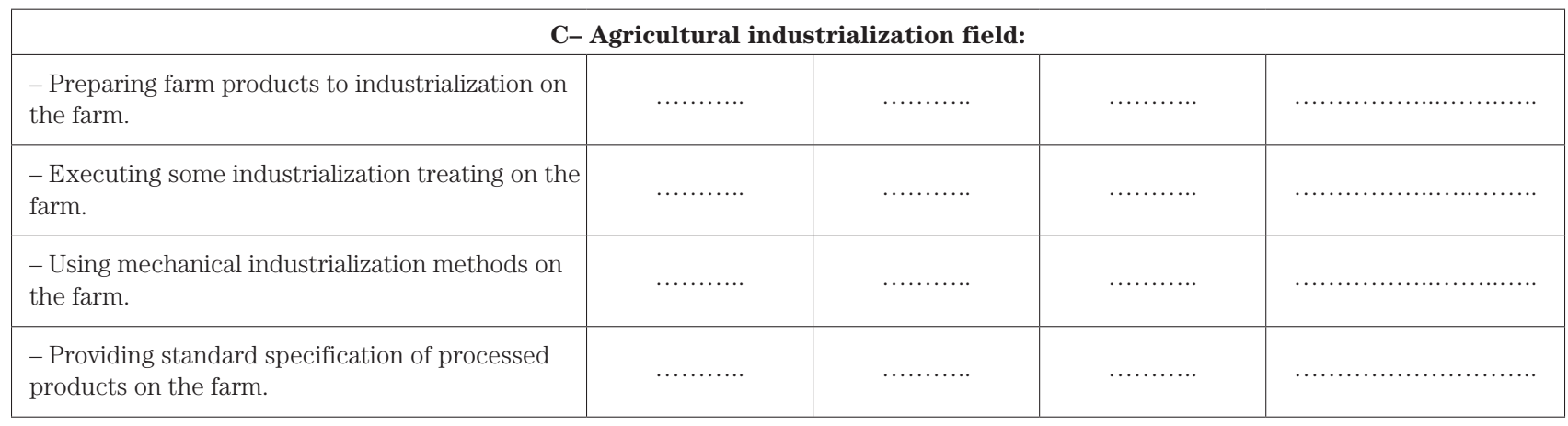

